九州大学学術情報リポジトリ

Kyushu University Institutional Repository

\title{
The Adsorption of Hydrogen Fluoride and Fluoride Ion on a Water Treatment Sludge
}

Oh, Taek-Keun

Biotron Institute, Kyushu University

Chikushi, Jiro

Biotron Institute, Kyushu University

Saeki, Kazutoshi

Biotron Institute, Kyushu University

https://doi.org/10.5109/14061

出版情報：九州大学大学院農学研究院紀要. 54 (1)，pp. 205-208，2009-02-27. Faculty of Agriculture, Kyushu University

バージョン：

権利関係 : 


\title{
The Adsorption of Hydrogen Fluoride and Fluoride Ion on a Water Treatment Sludge
}

\author{
Taek-Keun OH, Jiro CHIKUSHI* and Kazutoshi SAEKI
}

Biotron Institute, Kyushu University, Hakozaki, 6-10-1, Fukuoka 812-8581, Japan

(Received November 14, 2008 and accepted December 5, 2008)

\begin{abstract}
The hydrogen fluoride (HF) and fluoride ion $\left(\mathrm{F}^{-}\right)$adsorption potentials of a water treatment sludge were investigated in a batch mode as a function of $\mathrm{pH}$, contact time, initial fluoride concentrations, and other co-existing anions. The maximum removal of total fluoride was apparently observed at $\mathrm{pH}$ 5.1, whereas $\mathrm{HF}$ or $\mathrm{F}^{-}$adsorptions showed nearly $100 \%$ in $\mathrm{pH}$ range from 2.2 to 4.3. The $\mathrm{HF}$ or $\mathrm{F}^{-}$adsorption by the water treatment sludge has occurred rapidly during the initial 5-60 min and thereafter slowly increased until $48 \mathrm{~h}$. The other anions such as $\mathrm{SO}_{4}^{2-}, \mathrm{NO}_{3}^{-}$and $\mathrm{Cl}^{-}$have not adversely affected on extent of $\mathrm{HF}$ or $\mathrm{F}^{-}$ adsorption by the water treatment sludge.
\end{abstract}

\section{INTRODUCTION}

Fluoride in drinking water is known to have both beneficial and detrimental effects on animal health depending upon its concentration. For human beings, intake of $1.0-1.5 \mathrm{mg} \mathrm{L}^{-1}$ fluoride prevents dental and skeletal problems. However, the chronic ingestion above this level might cause the disease of mottling teeth, many types of bone diseases, and the lesions of endocrine glands, thyroid, liver, and other organs. The World Health Organization (WHO) proposed that the maximum concentration of fluoride in drinking water should not exceed $1.5 \mathrm{mg} \mathrm{L}^{-1}$ (WHO, 2006). High concentration of fluoride in water sources has been critical problems in much areas of the world where the fluoride concentration is of 0.01 to $3 \mathrm{mg} \mathrm{L}^{-1}$ in fresh water and of 1.0 to $35 \mathrm{mg} \mathrm{L}^{-1}$ in ground water. For example, a certain hot spring water in Korea contained $12.7 \mathrm{mg} \mathrm{L}^{-1}$ of fluoride (Lee, 2007) and the ground water in Japan, $2.3 \mathrm{mg} \mathrm{L}^{-1}$ (Tominaga et al., 2002).

There are a number of techniques for fluoride removal from water such as adsorption (Srimurali et al., 1998; Reardon and Wang, 2001), ion exchange (Vaaramaa and Lehto, 2003), and precipitation (Singh et al., 1999). Among these methods, the adsorption technique is most widely used for removing fluoride. Adsorbents have been used for defluoridation including activated alumina (Ghorai and Pant, 2004), activated carbon (Ramos et al., 1999), bone char (Bhargava and Killedar, 1992), and zeolites (Mayadevi, 1996). However, these adsorbents have some disadvantages in terms of removal efficiency, limited availability of materials, and disposal of treatment chemicals. Therefore, recent researches are focused on the development of lower cost agents and highly effective materials for fluoride removal (Fan et al., 2003).

Water treatment sludge is an inescapable by-product generated during the processing of drinking water.

\footnotetext{
Biotron Institute, Graduate School of Bioresource and Bioenvironmental Sciences, Kyushu University

* Corresponding author (E-mail: chiku2@agr.kyushu-u.ac.jp)
}

The sludge typically contains mineral and humic substances from water, together with any treatment chemicals used as coagulants. The water treatment sludge contains appreciable amounts of hydrous oxides with significant P-sorbing capacity (Elliott et al., 1990; Novak and Watts, 2004). The sludge with a rugged surface has shown a superior adsorption capability for fluoride (Sujana et al., 1998), copper and lead (Wu et al., 2004). The water treatment sludge has a potential adsorption capacity of fluoride. It can be utilized as a "low-cost" and potentially recyclable adsorbent. However, there is little information on the removal of fluoride by the water treatment sludge.

In this study, we investigated the water treatment sludge as an adsorbent for removing aqueous fluoride in respect of $\mathrm{pH}$, contact time, concentration, and other anions.

\section{MATERIALS AND METHODS}

\section{Sludge sample}

The water treatment sludge was supplied from a drinking water treatment plant located at Kurume, Fukuoka, Japan. The sludge was air-dried and then sieved $(<425 \mu \mathrm{m}$.). The chemical composition of the sludge was analyzed by the X-ray fluorescence analysis (Shimadzu, EDX -800) in the Analytical Center of Kyushu University, listed in Table 1. Aluminum oxide as $\mathrm{Al}_{2} \mathrm{O}_{3}$ was the dominant component (49.9\%).

\section{Reagents}

The fluoride solution was prepared sodium fluoride (NaF) supplied from Wako Chemicals. Alfusone, which is a mixed powder of $2.5 \%$ (w/w) La-ALC (mole ratio, 1:1) chelate with potassium hydrogen phthalate, and hexamethylenetetramine buffer, was purchased from Dojindo Laboratories (Kumamoto, Japan) for the chromogenic reagent of fluoride. The $1 \%$ alfusone solution was prepared by dissolving in distilled water (DW) at each analysis. The chemicals used in the all experiments were in analytical grade. 
Table 1. Principal chemical compositions of the water treatment sludge

\begin{tabular}{ccccccccccc}
\hline Composition & $\mathrm{Al}_{2} \mathrm{O}_{3}$ & $\mathrm{SiO}_{2}$ & $\mathrm{Fe}_{2} \mathrm{O}_{3}$ & $\mathrm{CaO}$ & $\mathrm{K}_{2} \mathrm{O}$ & $\mathrm{TiO}_{2}$ & $\mathrm{SO}_{3}$ & $\mathrm{P}_{2} \mathrm{O}_{5}$ & $\mathrm{MnO}$ & Total \\
\hline$(\%)$ & 49.9 & 40.0 & 5.6 & 1.4 & 1.4 & 0.6 & 0.4 & 0.4 & 0.3 & 100.0 \\
\hline
\end{tabular}

\section{Determination of $\mathrm{HF}$ or $\mathbf{F}^{-}$concentration}

The $\mathrm{HF}$ or $\mathrm{F}^{-}$concentration of the synthetic solutions was determined according to the method reported by Okumura et al. (2003). One milliliter of the $1 \%$ alfusone solution, $0.25 \mathrm{~mL}$ of filtrated solutions, $0.4 \mathrm{~mL}$ of buffer solution $\left(\mathrm{CH}_{3} \mathrm{COONa}\right)$, and $2 \mathrm{~mL}$ of acetone were added to a test tube. The final volumes were made up to $10 \mathrm{~mL}$ with DW. After $60 \mathrm{~min}, 620 \mathrm{~nm}$ absorbances of the mixtures were measured by a spectrophotometer (PerkinElmer, Lambda 10). The adsorption of fluoride was calculated from the difference between added fluoride and the final concentration in the solution.

\section{Effect of pH on adsorption}

The removal of fluoride ions is highly dependent on the $\mathrm{pH}$. The water treatment sludge contains mainly oxides of aluminum, iron and silica (Table 1). These oxides of the adsorbent in the aqueous medium would be hydroxylated to develop surface charge. In particular, the alumina, a main component of the sludge, has a good capacity for fluoride removal (Bahena et al., 2002). The removal of $\mathrm{HF}$ or $\mathrm{F}^{-}$by the sludge was investigated at $\mathrm{pH}$ ranging from 2.0 to 9.0 , which was prepared by adjusting $\mathrm{pH}$ with $0.1 \mathrm{~mol} \mathrm{~L}-1$ (M) $\mathrm{HClO}_{4}$ or $0.1 \mathrm{M} \mathrm{NaOH}$ solution in a $10 \mathrm{~mL}$ polyethylene centrifuge tube. Two milliliters of $0.5 \mathrm{M} \mathrm{NaClO}_{4}, 2 \mathrm{~mL}$ of $5 \mathrm{mM} \mathrm{NaF}$ solution and $0.1 \mathrm{~g}$ of the sludge also were placed in the tube. The final volumes were made up to $10 \mathrm{~mL}$ with distilled water. The suspensions were agitated for 24 hours in an airconditioned room at $298 \pm 1 \mathrm{~K}$. Thereafter, the suspensions were centrifuged at $2,100 \times g$ for $15 \mathrm{~min}$ and filtered through a $0.2 \mu \mathrm{m}$ Millipore filter. The sample obtained by filtrating was used for colorimetry analysis. In the addition of the $\mathrm{HF}$ or $\mathrm{F}^{-}$determination, total fluoride concentrations were measured with the method modified by the addition of acetylacetone as a demasking agent (Okumura et al., 2003).

\section{Effect of contact time on adsorption}

Adsorption experiments were conducted from 0 to $2880 \mathrm{~min}$. The sludge of $2.5 \mathrm{~g}$ and $50 \mathrm{~mL}$ of $0.5 \mathrm{M} \mathrm{NaClO}_{4}$ were placed into a plastic beaker. Then, a fluoride solution was added and was made up to $250 \mathrm{~mL}$ with adding distilled water. The initial concentration was $1 \mathrm{mM}$. After the pre-determined time intervals, the suspensions filtered and analyzed for the residual concentrations of $\mathrm{HF}$ or $\mathrm{F}^{-}$.

\section{Adsorption isotherm}

Langmuir and Freundlich equations are the most widely used isotherm models. Since the dried and ground sludge had heterogenic granulometria (Babatunde and Zhao, 2007; Tor, 2006), adsorption isotherm for the water treatment sludge was plotted using the Freundlich equation :

$$
X=K C^{1 / n}
$$

where $C$ is equilibrium fluoride concentration $\left(\mathrm{mg} \mathrm{L}^{-1}\right)$, $X$ is the adsorbed fluoride ( $\left.\mathrm{mg} \mathrm{Kg}^{-1}\right), K$ is a coefficient, and $n$ is the degree of linearity. To determine the coefficients $K$ and $n$, the equation (1) may be linearized by taking the logarithm of both sides. The linear form of Freundlich isotherm can be given as

$$
\log X=1 / n \log C+\log K
$$

A plot of $\log X$ versus $\log C$ should be linear and the $K$ (intercept) and $1 / n$ (slope) are the Freundlich coefficients related to adsorption capacity and adsorption intensity, respectively. A smaller value of $1 / n$ lying in the range of 0 to 1 indicates a stronger bond between adsorbate and adsorbent, while a higher value for $K$ showed more adsorption of adsorbate from a synthetic solution (Rao and Bhole, 2001; Raji and Anirudhan, 1997).

One gram of the sludge, $20 \mathrm{~mL}$ of $\mathrm{NaClO}_{4}$ and $50 \mathrm{~mL}$ of distilled water were placed in a $200 \mathrm{~mL}$ plastic beaker. The suspension was adjusted to pH 5.0 with $0.1 \mathrm{M} \mathrm{HClO}_{4}$ or $0.1 \mathrm{M} \mathrm{NaOH}$ during $24 \mathrm{~h}$. Then, $20 \mathrm{~mL}$ of the fluoride solutions from 0 to $100 \mathrm{mM}$ was added the plastic beaker and DW was added to $100 \mathrm{~mL}$. The suspensions were stirred for 24 hours and centrifuged at $2,100 \times g$ for $15 \mathrm{~min}$, then passed through $0.22 \mu \mathrm{m}$ Millipore filter. The filtrate was analyzed for $\mathrm{HF}$ or $\mathrm{F}^{-}$concentrations by the same methods as above. The experiments were conducted in $298 \pm 1 \mathrm{~K}$.

\section{Effect of other anions on adsorption}

Fluoride adsorption experiments were conducted in the mixed solution of fluoride and other anions like chloride, sulfate, and nitrate. The concentrations of $0,1.0$, 10.0, and $100 \mathrm{mM}$ for anions of $\mathrm{SO}_{4}^{2-}, \mathrm{NO}_{3}^{-}$and $\mathrm{Cl}^{-}$were prepared respectively by dissolving of their sodium salts in $1 \mathrm{mM}$ fluoride solution. The prepared solutions were placed in the polyethylene tube with $0.15 \mathrm{~g}$ of the water treatment sludge. The solution was agitated for $24 \mathrm{~h}$ at $298 \pm 1 \mathrm{~K}$ and filtered. The concentration of $\mathrm{HF}$ or $\mathrm{F}^{-}$in the filtrate was determined by the same methods as above.

\section{RESULTS AND DISCUSSION}

\section{Effect of pH on adsorption}

The effect of $\mathrm{pH}$ on the adsorption of fluoride may be attributed to factors such as the activation of the adsorbent species (Çengeloglu et al., 2002). The results are shown in Fig. 1. The adsorption percentage of total fluoride species apparently increased with increasing $\mathrm{pH}$ and reached a maximum of $84.58 \%$ at $\mathrm{pH}$ 5.1. Then the adsorption of total fluoride species decreased sharply 


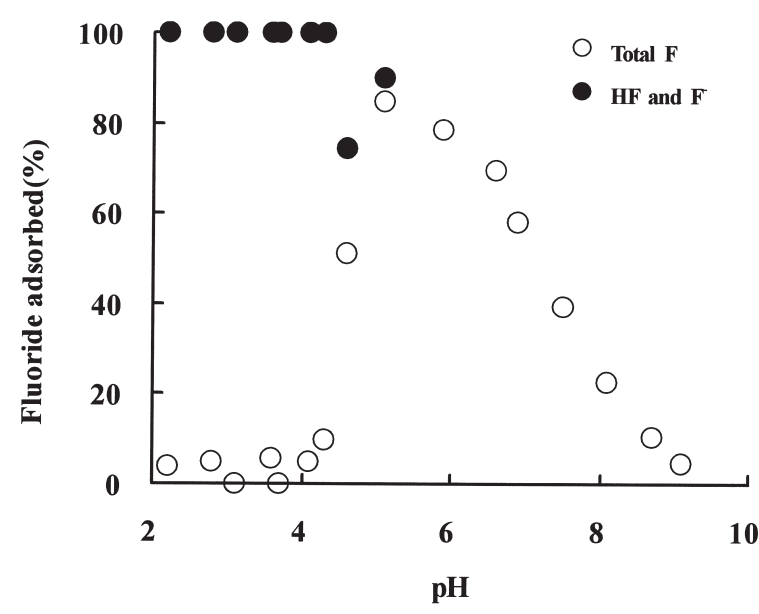

Fig. 1. Adsorption of fluoride as a function of $\mathrm{pH}$. Conditions: adsorbent $0.1 \mathrm{~g}$, fluoride concentration $(\mathrm{NaF})$ $1 \mathrm{mM}$, time $24 \mathrm{~h}, \mathrm{NaClO}_{4} 0.1 \mathrm{M}$, final volume $10 \mathrm{~mL}$.

and only $4.41 \%$ was adsorbed at $\mathrm{pH} 9.0$. The adsorption percentage of $\mathrm{HF}$ or $\mathrm{F}^{-}$showed nearly $100 \%$ within the $\mathrm{pH}$ range from 2.2 to 4.3. It meant that fluoride at $\mathrm{pH}<$ approximately 4.3 existed with soluble metal-fluoride such as fluoro-aluminates complexes $\left(\mathrm{AlF}_{n}^{3-n}\right)$. Also, it was found that metal-fluoride complexes have been dissociated from adsorbent surface and then the fluoride separated from the metal-fluoride complexes by acetylacetone existed with conformations such as $\mathrm{HF}$ or $\mathrm{F}^{-}$. The hydroxyl groups on the adsorbent surface in high $\mathrm{pH}$ range negatively charged with increasing $\mathrm{pH}$, written as :

$$
\mathrm{AlOH}+\mathrm{OH}^{-}=\mathrm{AlO}^{-}+\mathrm{H}_{2} \mathrm{O}
$$

Consequently, the less adsorption capacity in solution of the range more than $\mathrm{pH} 5.1$ would be due to the $\mathrm{F}^{-}$ions cannot be adsorbed with $\mathrm{AlO}^{-}$.

\section{Effect of contact time on adsorption}

The variation of $\mathrm{HF}$ or $\mathrm{F}^{-}$adsorbed with contact times is shown in Fig. 2. The removal of $\mathrm{HF}^{\text {or }} \mathrm{F}^{-}$increased significantly in the early period within 5-60 min and

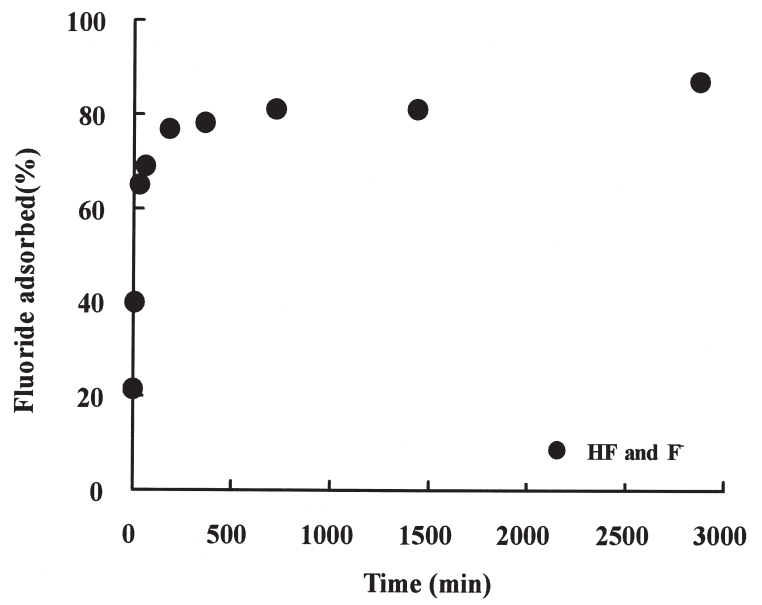

Fig. 2. Adsorption of fluoride as a function of contact time (min). Conditions: adsorbent $2.5 \mathrm{~g}$, fluoride concentration (NaF) $1 \mathrm{mM}, \mathrm{NaClO}_{4} 0.1 \mathrm{M}$, final volume $250 \mathrm{~mL}$. thereafter slowed, but continuously increased until $48 \mathrm{~h}$. The adsorption percentage of $\mathrm{HF}$ or $\mathrm{F}^{-}$was found to be $86.84 \%$ after $48 \mathrm{~h}$ (2880 $\mathrm{min})$. The result is in good agreement with the literatures by other workers, which reported that the removal of fluoride by alum-impregnated activated alumina was rapid, that is, most of the fluoride was removed within 10-60 min (Tripathy et al., 2006) and fluoride removal of $72 \%$ by the magnesiaamended activated alumina granules took place in first 60 min (Maliyekkal et al., 2007).

\section{Adsorption isotherm}

Analysis of isotherm data is important for predicting adsorption capacities of adsorbents, which is one of the main parameter required for the design of an adsorption system (Maliyekkal et al., 2007). The adsorption isotherm experiments were carried out to determine maximum fluoride adsorption by the sludge, shown in Fig. 3. The isotherm showed that the adsorption of $\mathrm{HF}$ or $\mathrm{F}^{-}$increased with increasing equilibrium concentration of fluoride, thereafter, became flat at higher equilibrium concentrations. The correlation coefficient $\left(R^{2}\right)$ values (0.982) showed that the Freundlich isotherm fitted well with the experimental data of the sludge.

The values of $K$ and $1 / n$ in the adsorption of HF or $\mathrm{F}^{-}$, determined from the intercept and the slope, were 4.396 and $0.822(n=1.216)$, respectively. Raji and Anirudhan (1997) reported that a smaller value of $1 / n$ lying in the range of $0-1$ and value of $n$ lying in the range of 1-10 confirms the favorable conditions for adsorption. Therefore, the adsorption of $\mathrm{HF}$ or $\mathrm{F}^{-}$onto the sludge indicated a favorable conditions because of the $1 / n$ values lower than 1 . Also, the higher value of $n$ indicated that the surface of the sludge was heterogeneous and potential adsorbent for fluoride adsorption.

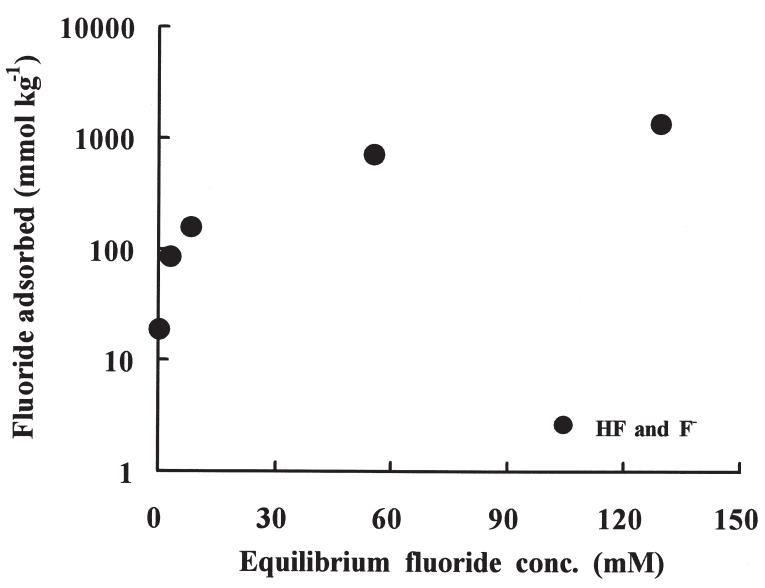

Fig. 3. Adsorption isotherm of fluoride. Conditions: adsorbent $1 \mathrm{~g}, \mathrm{pH} 5.0$, time $24 \mathrm{~h}, \mathrm{NaClO}_{4} 0.1 \mathrm{M}$ temperature $298 \pm 1 \mathrm{~K}$, final volume $100 \mathrm{~mL}$.

\section{Effect of other anions on adsorption}

The adsorption percentage of $\mathrm{HF}^{-}$or $\mathrm{F}^{-}$in the solutions added $\mathrm{SO}_{4}^{2-}, \mathrm{NO}_{3}^{-}$and $\mathrm{Cl}^{-}$increased 18.3, 26.2, and $20.9 \%$, respectively (Table 2 ). We found that the coexisting anions such as $\mathrm{SO}_{4}^{2-}, \mathrm{NO}_{3}^{-}$, and $\mathrm{Cl}^{-}$have not 
Table 2. Effect of co-existing anions on fluoride adsorption by the sludge

\begin{tabular}{ccccc}
\hline \multirow{2}{*}{$\begin{array}{c}\text { Co-existing } \\
\text { anions }\end{array}$} & \multicolumn{5}{c}{ Concentration of anions (mM) } \\
\cline { 2 - 5 } & 0 & 1 & 10 & 100 \\
\hline \multicolumn{5}{c}{ Fluoride adsorbed (\%) } \\
$\mathrm{Na}_{2} \mathrm{SO}_{4}$ & 65.3 & 67.1 & 75.8 & 83.6 \\
$\mathrm{NaNO}_{3}$ & 64.0 & 66.5 & 78.6 & 90.2 \\
$\mathrm{NaCl}$ & 70.1 & 73.2 & 83.6 & 91.0 \\
\hline
\end{tabular}

adversely effected on removal efficiency of $\mathrm{HF}$ or $\mathrm{F}^{-}$onto the sludge. It was in an agreement with to the similar works done by other workers (Maliyekkal et al., 2007; Lv et al., 2006; Lv et al., 2007; Shen et al., 2003), especially Karthikeyan et al. (1997) was found that the fluoride adsorption efficiency onto activated alumina is not significantly affected by the presence of the other anions like $\mathrm{SO}_{4}^{2-}, \mathrm{NO}_{3}^{-}$and $\mathrm{Cl}^{-}$.

\section{CONCLUSIONS}

In the present study, a water treatment sludge has been investigated as adsorbent for utilization in removing fluoride from the solutions. The optimum adsorption of total fluoride species from sample solution was apparently occurred at $\mathrm{pH} 5.1$, but $\mathrm{HF}$ or $\mathrm{F}^{-}$adsorbed nearly $100 \%$ at the range less than $\mathrm{pH}$ 4.3. Fluoride adsorption by the sludge was found to be very rapid during the initial period, namely, most of the $\mathrm{HF}$ or $\mathrm{F}^{-}$was removed during 5-60 min and thereafter slowed, continuously increased until $48 \mathrm{~h}$. The adsorption data were fitted well by the Freundlich equation with higher correlation coefficient values. We found that the increase of co-existing anions such as $\mathrm{SO}_{4}^{2-}, \mathrm{NO}_{3}^{-}$, and $\mathrm{Cl}^{-}$to $100 \mathrm{mM}$ have not adversely effected on the adsorption efficiency of HF or $\mathrm{F}^{-}$onto the sludge. The water treatment sludge, an inescapable by-product of water treatment processes, can be expected to be reused as a adsorbent removal capacity for fluoride.

\section{REFERENCES}

Babatunde A. O. and Y. Q. Zhao 2007 Constructive approaches toward water treatment works sludge management: An international review of beneficial reuses. Critical reviews in Envrion. Sci. Tech., 37: 129-164

Bahena J. L. R., A. R. Cabrera, A. L. Valdivieso and H. Urbina 2002 Fluoride adsorption onto $\alpha-\mathrm{Al}_{2} \mathrm{O}_{3}$ and its effect on the zeta potential at the alumina-aqueous electrolyte interface. Sep. Sci. Tech., 37(8): 1973-1987

Bhargava D. S. and D. J. Killedar 1992 Fluoride adsorption on fishbone charcoal through a moving media absorber. Wat. Res., 26: $781-788$

Çengeloglu Y., E. Kir and M. Ersöz 2002 Removal of fluoride from aqueous solution by using red mud Sep. Purif. Tech., 28: 81-86

Elliott H. A., B. A. Dempsey and P. J. Maille 1990 Content and fractionation of heavy metals in water treatment sludges. $J$. Environ. Qual., 19(2): 330-334

Fan X., D. J. Parker and M. D. Smith 2003 Adsorption kinetics of fluoride on low cost materials. Water Res., 37: 4929-4937

Ghorai S.and K. K. Pant 2004 Investigations on the column per- formance of fluoride adsorption by activated alumina in a fixedbed. Chem. Eng. J., 98: 165-173

Karthikeyan G., B. V. Apparao and S. Meenakshi 1997 Mechanistic Studies of the Defluoridation Property of Activated Alumina. Proceedings of the Second International Workshop on Fluorosis and Defluoridation of Water, pp. 19-25

Lee H. K. 2007 A Study on the Characteristics of Water Quality and the Efficient Elimination Method of Fluoride in Sulfur Hot Spring Water. Diss. University of Chonbuk National

Lv L., J. He, M. Wei, D. G. Evans and X. Duan 2006 Factors influencing the removal of fluoride from aqueous solution by calcined $\mathrm{Mg}-\mathrm{Al}-\mathrm{CO}_{3}$ layered double hydroxides. J. Hazardous Materials B, 133: 119-128

Lv L., J. He, M. Wei, D. G Evans and Z. Zhou 2007 Treatment of high fluoride concentration water by $\mathrm{MgAl}-\mathrm{CO}_{3}$ layered double hydroxides: Kinetic and equilibrium studies. Water Res., 41 1534-1542

Maliyekkal S. M., S. Shukla and L. Philip 2007 Enhanced fluoride removal from drinking water by magnesia-amended activated alumina granules. Chem. Eng. J., 140: 183-192

Mayadevi S. 1996 Adsorbents for the removal of fluoride from water. Indian Chem. Eng., 38: 155-157

Novak J. M. and D. W. Watts 2004 Increasing the phosphorus sorption capacity of southeastern coastal plain soils using water treatment residuals. Soil Sci., 169(3): 206-214

Okumura M., T. Yoshimura, K. Fujinaga and Y. Seike 2003 Direct spectrophotometric determination of traces of fluoride in rain water. Jpn. Soc. Anal. Chem., 52(6): 485-488

Raji C. and T. S. Anirudhan 1997 Chromium (VI) adsorption by sawdust carbon: kinetics and equilibrium. Indian J. Chem. Tech. 4: 228-236

Ramos R. L., J. O. Turrubiartes and M. A. S. Castillo 1999 Adsorption of fluoride from aqueous solution on aluminium-impregnated carbon. Carbon, 37: 609-617

Rao M. and A. G. Bhole 2001 Chromium removal by adsorption using fly ash and bagasse. J. Indian Water Works Assoc., 33(1): 97-100

Reardon E. J. and Y. Wang 2001 Activation and regeneration of a soil sorbent for defluoridation of drinking water. Appl. Geochem., 16: 531-539

Shen F., X. Chen, P. Gao, and G. Chen 2003 Electrochemical removal of fluoride ions from industrial wastewater. Chem Eng. Sci., 58: 987-993

Singh G., B. Kumar, P. K. Sen and J. Majumdar 1999 Removal of fluoride from spent pot liner leachate using ion exchange. Water Environ. Res., 71: 36-42

Srimurali M., A. Pragathi and J. Karthikeyan 1998 A study on removal of fluorides from drinking water by adsorption onto low-cost materials. Environ. Pollution, 99: 285-289

Sujana M. G., R. S. Thakur and S. B. Rao 1998 Removal of fluoride from aqueous solution using alum sludge. J. Colloid Interface Sci., 206(1): 94-101

Tominaga T., J. Ishibashi and N. Shimada 2002 Geochemistry of groundwater in the Hakozaki/-/Hakomatsu area with special reference to fluorine contamination. Jpn. Geosic. Uni., H060 P003

Tor A. 2006 Removal of fluoride from an aqueous solution by using montmorillonite. Desalination, 201: 267-276

Tripathy S. S., J. L. Bersillon and K. Gopal 2006 Removal of fluoride from drinking water by adsorption onto alum-impregnated activated alumina. Sep. Purif. Tech., 50: 310-317

Vaaramaa K. and J. Lehto 2003 Removal of metals and anions from drinking water by ion exchange. Desalination, 155 : $157-170$

WHO 2006 Guidelines for Drinking-water Quality, third ed. 1st Addendum to vol. 1. WHO

Wu C. H., C. F. Lin and P. Y. Horng 2004 Adsorption of copper and lead ions onto regenerated sludge from a water treatment plant J. Environ. Sci Health A, 39(1): 237-252 